\title{
Analisis Kemampuan Pemecahan Masalah Matematis Siswa SMP Pada Materi Teorema Pythagoras
}

\author{
Alfi Rahmawati ${ }^{1}$, Attin Warmi ${ }^{2}$, Rina Marlina ${ }^{3}$ \\ 1,2,3 Program Studi Pendidikan Matematika, Fakultas Ilmu Pendidikan, Universitas Singaperbangsa Karawang, Jl. HS \\ Ronggo Waluyo, Puseurjaya, Kec.Telukjambe Timur, Karawang, Jawa Barat, Indonesia \\ alfi.rahmawati17043@student.unsika.ac.id
}

\begin{abstract}
The purpose of this study is to examine students' abilities to solve mathematical problems using Pythagorean theorem material. The subjects of this study were class IX students at SMPN 16 Bekasi, a class of 26 kids who were chosen using a purposive sampling technique, in which three students were chosen based on their ability to solve mathematical problems at a high, medium, or low level. The researchers themselves served as the instruments in this study, along with supporting instruments such as test instruments for students' mathematical problem-solving ability and interview procedures. The findings indicated that while students in the high ability category were capable of solving the issues, they were less comprehensive in their reading of the questions. Students in the medium ability category were unable to solve the provided problem since they could only comprehend it. Students classified as poor ability have been unable to answer the given challenge because they continue to struggle to comprehend the supplied problem.
\end{abstract}

Keywords: Mathematical problem solving ability, Pythagorean theorem.

\begin{abstract}
Abstrak
Penelitian ini mempunyai tujuan menganalisa kemampuan siswa menyelesaikan persoalan matematika memakai materi teorema Pythagoras. Objek penelitian ini yakni siswa kelas IX SMPN 16 Bekasi dengan jumlah 26 siswa, memakai teknik purposive sampling, yakni memilih 3 siswa menurut kategori kemampuan menyelesaikan masalah matematika tinggi, sedang, serta rendah. Alat bantu di penelitian ini yakni peneliti sendiri dengan alat tes serta pedoman wawancara bagi kemampuan menyelesaikan masalah matematika siswa. Hasil penelitian memperlihatkan siswa dengan berkemampuan tinggi bisa menyelesaikan soal, namun mereka kurang serius membaca soal. Siswa pada kategori kemampuan sedang tak bisa mengerjakan soal yang karena hanya bisa memahami masalah yang diberikan. Siswa dengan kemampuan rendah tak dapat mengerjakan soal yang ada sebab masih kesulitan memahami soal.
\end{abstract}

Kata kunci: Kemampuan pemecahan masalah matematis, teorema Pythagoras

$\triangle$ Corresponding author: Alfi Rahmawati

Copyright (c) 2022 Alfi Rahmawati, Attin Warmi, Rina Marlina

Email Address: alfi.rahmawati17043@student.unsika.ac.id (Jl. HS. Ronggo Waluyo, Karawang, Jawa Barat)

Received 27 August 2021, Accepted 07 October 2021, Published 18 Januari 2022

\section{PENDAHULUAN}

Matematika yakni ilmu yang mempelajari tentang konsep-konsep yang tersusun dengan teratur, terstruktur serta sistematis diawali konsep sederhana sampai hingga kompleks (Ekananda et al., 2020). Dengan konsep yang hierarki tersebut akan mempermudah memahami permasalahan matematika. (NCTM, 2000) Diputuskan bahwa siswa harus menguasai lima proses standar lewat pembelajaran matematika, yakni: (1) pemecahan masalah; (2) penalaran serta pembuktian; (3) koneksi; (4) komunikasi; (5) representatif. Oleh karena itu, diharapkan siswa mempunyai kemampuan memecahkan masalah matematika supaya bisa memperoleh solusi dari masalah matematika.

Kemampuan pemecahan masalah matematika penting sekali untuk siswa sebab bisa mengembangkan kognitif siswa dan memudahkan siswa dalam memahami masalah serta menyelesaikan masalah yang diberikan. Rosmawati mengatakan bahwa kemampuan pemecahan matematika ialah bagian sangat penting dari kurikulum matematika sebab memudahkan siswa 
mengembangkan keterampilan intelektual dan mengetahui bagaimana langkah-langkah pemecahan masalah. (Af-idah \& Suhendar, 2020). Artinya siswa membutuhkan kemampuan memahami informasi yang diberikan, menganalisis serta mengatur strategi yang tepat untuk menyelesaikan suatu permasalahan. Semakin sering siswa dihadapkan dengan suatu permasalahan, Kemudian siswa bakal terbiasa dengan cara berpikirnya sehingga bisa membantunya menyelesaikan kehidupan sehari-hari (Maharani \& Bernard, 2018).

Pemecahan masalah didefinisikan sebagai proses kegiatan aktif yang diadopsi oleh seseorang, termasuk metode, prosedur, dan strategi untuk memecahkan masalah sampai selesai dan memenuhi persyaratan. Sejalan dengan Intaros et al. (2014) Keterampilan pemecahan masalah mendorong siswa memakai konsep serta strategi mereka sendiri untuk memecahkan masalah matematika. Terdapat empat tahapan pemecahan masalah yang dapat dilakukan menurut Polya (1988), antara lain "Understanding the problem (Memahami Masalah), Devising a Plan (Menyusun Rencana Pemecahan Masalah), Carrying out the Plan (Melaksanakan Rencana), dan Looking Back (Memeriksa Kembali)".

Rendahnya kemampuan pemecahan masalah matematis siswa bisa diketahui dari berbagai penelitian. Menurut hasil studi pendahuluan Nur Indah Sari (2020), kemampuan pemecahan masalah matematis siswa SMP Negeri 1 Bagan Sinembah secara keseluruhan ada di kategori kurang, dengan rata-rata 3,12. Sementara temuan penelitian Abdiyani et al. (2019) di SMP Negeri 1 Jogoroto menunjukkan kemampuan pemecah masalah siswa rendah dimana $60 \%$ siswa kesulitan menyelesaikan soal matematika, utamanya di model simbol serta mengartikan petunjuk menyelesaikan soal.

Menurut hasil penelitian pendahuluan peneliti pada siswa SMP, siswa mempunyai masalah pengerjaan soal yang masih kurang, ini dikarenakan siswa memiliki pemahaman konsep yang kurang memadai secara keseluruhan. Berikut ini adalah uraian jawaban siswa terhadap kemampuan pemecahan masalah matematika siswa di materi Pythagoras.

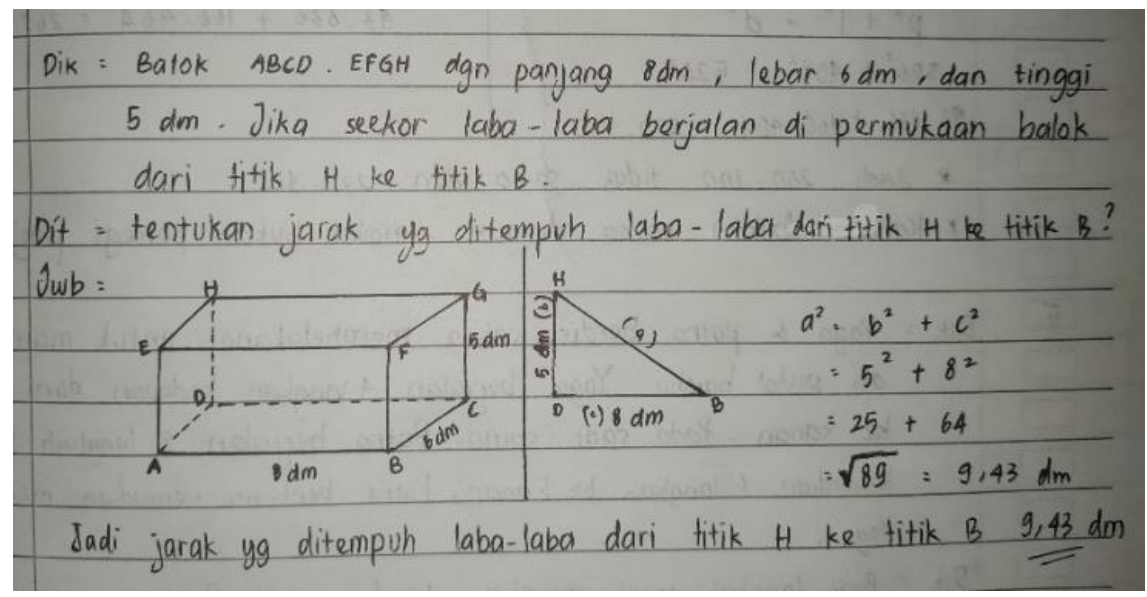

Gambar 1. Jawaban Siswa RA

Kesalahan jawaban siswa RA adalah salah menyusun rencana penyelesaian dengan menganggap panjang BA sebagai BD yaitu $8 \mathrm{dm}$. Kemudian dalam melaksanakan penyelesaian 
Analisis Kemampuan Pemecahan Masalah Matematis Siswa SMP pada Materi Teorema Pythagoras, Alfi Rahmawati, Attin Warmi, Rina Marlina

masalahnya siswa langsung mencari panjang HB yang ia anggap sebagai $a$, DH sebagai $b$ dan menggunakan panjang BD yang dianggap $8 \mathrm{dm}$ sebagai $c$. Sehingga hasil jawaban yang diperoleh RA salah yaitu 9,43 dm. Siswa RA hanya memberikan kesimpulan dan tidak menuliskan cara ia memeriksa kembali jawaban. Dengan demikian peneliti tertarik menganalisa kemampuan pemecahan masalah matematis siswa SMP di materi teorema Pythagoras.

\section{METODE}

Penelitian ini memakai metode penelitian deskriptif kualitatif. Tujuan metode penelitian deskriptif kualitatif ini yakni menyusun deskripsi dan gambaran sistematis kondisi yang terjadi dilapangan, yaitu guna menganalisa kemampuan menyelesaikan masalah matematis siswa SMP di materi Pythagoras. Adapun subjek penelitiannya yakni 26 siswa kelas IX di SMPN 16 Bekasi. Pemilihan subjek memakai teknik purposive sampling, dipilih 3 siswa menurut kategori kemampuan pemecahan masalah matematis tinggi, sedang, serta rendah memakai rumus dari (Arikunto, 2018) berikut.

Tabel 1. Kategori Kemampuan Pemecahan Masalah Matematis

\begin{tabular}{|l|l|}
\hline Kriteria & Kategori \\
\hline$x \geq \bar{x}+S D$ & Tinggi \\
\hline$x-S D<X>(\bar{x}+S D)$ & Sedang \\
\hline$x \leq \bar{x}-S D$ & Rendah \\
\hline
\end{tabular}

Instrumen di penelitian ini yakni peneliti sendiri dengan instrumen pendukung, yakni instrumen tes kemampuan pemecahan masalah matematis siswa yang diadopsi dari tesis milik Towe (2019) berupa 2 butir soal uraian teorema Pythagoras dan pedoman wawancara. Kemampuan pemecahan masalah siswa dianalisa menurut fase pemecahan masalah oleh Polya dengan pedoman penskoran yang dikembangkan oleh Ariani et al. (2017) dapat dilihat pada Tabel 2.

Tabel 2. Pedoman Penskoran Kemampuan Pemecahan Masalah Matematis

\begin{tabular}{|l|l|c|}
\hline Aspek yang dinilai & \multicolumn{1}{|c|}{ Reaksi Terhadap Soal } & Skor \\
\hline Memahami Masalah & Tidak ada jawaban sama sekali & 0 \\
\cline { 2 - 3 } & $\begin{array}{l}\text { Menuliskan diketahui/ditanyakan/gambar tetapi salah atau tidak } \\
\text { memahami masalah sama sekali }\end{array}$ & 1 \\
\cline { 2 - 3 } & $\begin{array}{l}\text { Memahami informasi atau permasalahan dengan kurang } \\
\text { tepat/lengkap }\end{array}$ & 2 \\
\cline { 2 - 3 } $\begin{array}{l}\text { Menyusun } \\
\text { Penyelesaian } \\
\text { Masalah }\end{array}$ & Rencanail memahami masalah secara menyeluruh & 3 \\
\cline { 2 - 3 } & $\begin{array}{l}\text { Sidak ada urutan langkah penyelesaian sama sekali } \\
\text { tidak/belum jelas }\end{array}$ & 1 \\
\cline { 2 - 3 } & $\begin{array}{l}\text { Strategi/langkah penyelesaian mengarah pada jawaban yang } \\
\text { benar tetapi tidak lengkap atau jawaban salah }\end{array}$ & 2 \\
\cline { 2 - 3 } & Menyajikan langkah penyelesaian yang benar & 0 \\
\hline Melaksanakan & Tidak ada penyelesaian sama sekali & 3 \\
\hline
\end{tabular}




\begin{tabular}{|l|l|c|}
\hline $\begin{array}{l}\text { Rencana } \\
\text { Penyelesaian } \\
\text { Masalah }\end{array}$ & Ada penyelesaian, tetapi prosedur tidak jelas/salah & 1 \\
\cline { 2 - 4 } & $\begin{array}{l}\text { Menggunakan prosedur tertentu yang benar tetapi perhitungan } \\
\text { salah/kurang lengkap }\end{array}$ & 2 \\
\cline { 2 - 4 } $\begin{array}{l}\text { Memeriksa Kembali } \\
\text { Jawaban }\end{array}$ & $\begin{array}{l}\text { Jika tidak menuliskan kesimpulan dan tidak melakukan } \\
\text { pengecekan terhadap proses juga hasil jawaban }\end{array}$ & 0 \\
\cline { 2 - 3 } & $\begin{array}{l}\text { Jika menuliskan kesimpulan dan/atau melakukan pengecekan } \\
\text { terhadap proses dengan kurang tepat atau Jika hanya } \\
\text { menuliskan kesimpulan saja atau melakukan pengecekan } \\
\text { terhadap proses saja dengan tepat }\end{array}$ & 1 \\
\cline { 2 - 2 } & $\begin{array}{l}\text { Jika menuliskan kesimpulan dan melakukan pengecekan } \\
\text { terhadap proses dengan tepat }\end{array}$ & 2 \\
\hline
\end{tabular}

Teknik analisis data kualitatif mengacu ke analisis data model Miles serta Huberman meliputi reduksi data, penyajian data, serta pengambilan kesimpulan (Chabibah et al., 2019). Uji keabsahan data memakai triangulasi dari memperbandingkan hasil tes serta wawancara.

\section{HASIL DAN DISKUSI}

\section{Hasil}

Berikut hasil kategorisasi tes kemampuan pemecahan masalah matematis yang telah diberikan kepada 26 siswa.

Tabel 3. Hasil Kategorisasi Tes Kemampuan Pemecahan Masalah Matematis Siswa

\begin{tabular}{|c|l|c|}
\hline Kategori & \multicolumn{1}{|c|}{ Kriteria } & Jumlah Siswa \\
\hline Tinggi & skor $\geq 14,536$ & 4 \\
\hline Sedang & $6,003<$ skor $>14,536$ & 18 \\
\hline Rendah & skor $\leq 6,003$ & 4 \\
\hline
\end{tabular}

Berdasarkan tabel 3 diketahui sebanyak 4 siswa yang mempunyai kemampuan pemecahan masalah matematis kategori tinggi memiliki skor lebih dari 14,536, sedangkan sebanyak 18 siswa dengan kemampuan pemecahan masalah matematis kategori sedang memiliki skor diantara 6,003 14,536, namun sebanyak 4 siswa dengan kemampuan pemecahan masalah matematis kategori rendah memiliki skor kurang dari 6,003.

\section{Diskusi}

Berikut analisis jawaban siswa dua soal tes uraian kemampuan pemecahan masalah matematis dengan subjek yang diambil yaitu BD dengan kategori tinggi, FFL dengan kategori sedang, dan RR dengan kategori rendah.

\section{Soal 1}

Suatu hari, Gilbert serta Duny berencana untuk berlibur ke pantai. Gilbert memilih Duny dan pergi ke pantai. Rumah Gilbert ada di bagian barat Duny's, serta pantai yang bakal mereka tuju berada tepat di utara Duny's. Jarak antara rumah Gilbert serta Duny yakni 15 kilometer, dan rumah Duny berjarak 20 
Analisis Kemampuan Pemecahan Masalah Matematis Siswa SMP pada Materi Teorema Pythagoras, Alfi Rahmawati, Attin Warmi, Rina Marlina

kilometer dari pantai. Apabila kecepatan rata-rata sepeda motor Gilbert $30 \mathrm{~km} / \mathrm{jam}$, tentukan perbedaan waktu yang diperlukan Gilbert antara menjemput Duny dan langsung ke pantai sendirian!

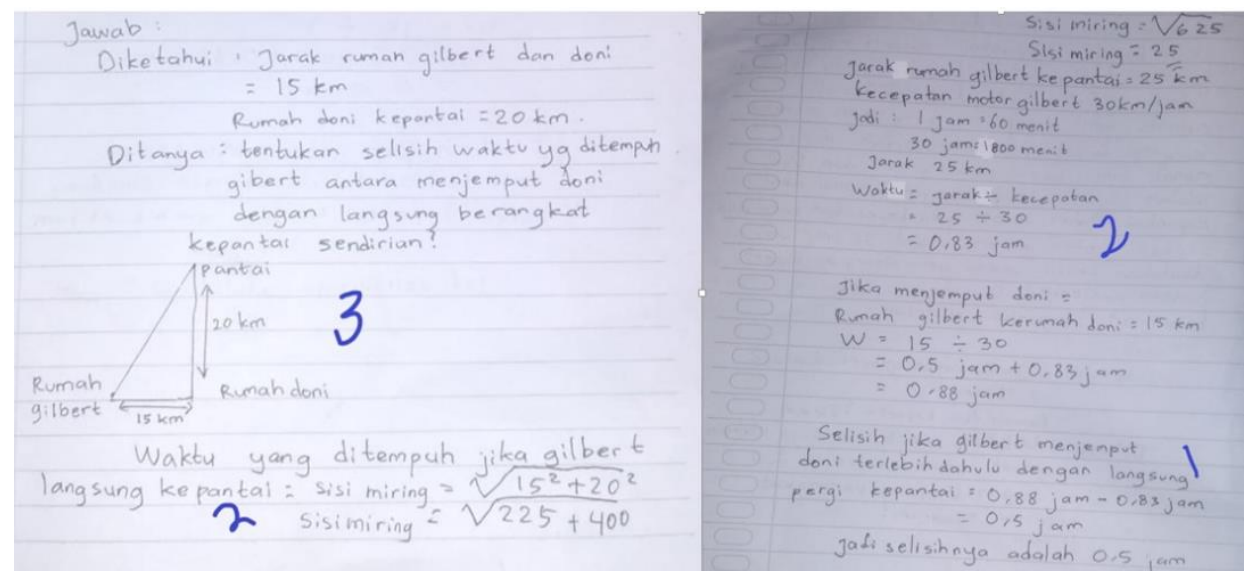

Gambar 2. Hasil Jawaban BD Untuk Soal 1

Berdasarkan hasil jawaban siswa BD terlihat mampu memahami soal dengan menuliskan unsurunsur yang diketahui, mengajukan pertanyaan, serta membuat gambar lengkap. Ketika BD sedang mempersiapkan rencananya, dia salah memahami pertanyaan yang diajukan, yaitu perbedaan waktu antara Gilbert untuk menjemput Duny dan Gilbert untuk langsung pergi ke pantai. Sejalan dengan penelitian Anggraeni \& Kadarisma (2020), Subjek menjawab pertanyaan tetapi mengalami kesalahan karena rencananya tidak sesuai dengan informasi yang diberikan. Oleh karena itu, hasil jawaban diberikan subjek tak sesuai urutan pada soal. Namun, subjek BD terus menerapkan solusi dan berakhir dengan pemahamannya. Subjek BD juga menguasai konsep-konsep dalam topik, termasuk yang memiliki kemampuan kuat, namun siswa harus lebih berhati-hati dalam memahami kalimat dalam topik.

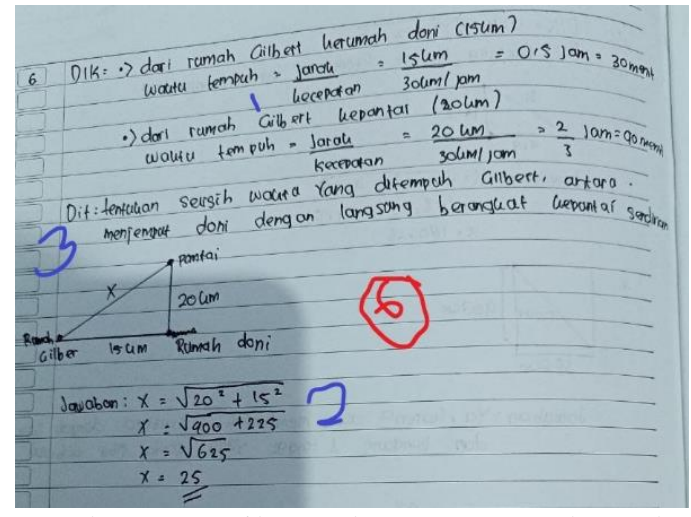

Gambar 3. Hasil Jawaban FFL Untuk Soal 1

Berdasarkan hasil jawaban siswa FFL, tampak bisa memahami masalah dengan menulis unsur yang diketahui, ditanyakan serta membuat gambar secara lengkap. Subjek berhasil mengetahui jarak antara rumah gilbert langsung menuju pantai dengan rumus pythagoras namun subjek tidak menyusun rencana untuk menemukan selisih waktu tempuh. Sejalan dengan penelitian Anggraeni \& Kadarisma (2020), Kesalahan siswa dalam menentukan penyelesaian yaitu sulit menentukan cara 
mencari selisih serta pelengkapnya. Sehingga pada soal 1 subjek FFL tidak memenuhi tahap kemampuan pemecahan masalah mulai dari tahap menyusun rencana pemecahan masalah. Kesalahan itu disebabkan siswa belum fahan penuh untuk menghubungkan materi teorema Pythagoras dengan materi lain (Anggraeni \& Kadarisma, 2020).

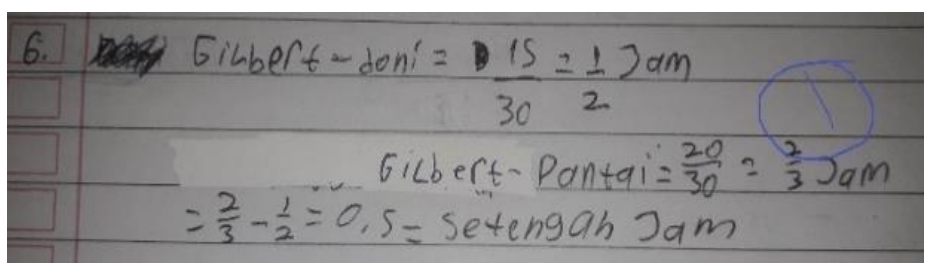

Gambar 4. Hasil Jawaban RR Untuk Soal 1

Berdasarkan hasil jawaban siswa RR, tampak tak menuliskan unsur yang diketahui, ditanyakan serta tidak membuat gambar dari permasalahan yang diberikan. Dari hasil jawaban yang diberikan pun subjek tampak salah dalam merencanakan penyelesaian, Yaitu, perbedaan waktu Gilbert untuk menjemput Duny dan waktu Gilbert untuk pergi langsung ke pantai, perbedaan antara waktu Gilbert untuk menjemput Duny ke pantai dan waktu Gilbert untuk pergi ke pantai sendirian, sehingga menghasilkan jawaban yang salah. Sejalan dengan penelitian Akbar et al. (2017), Subjek tak terbiasa menuliskan beragan informasi yang terkandung dalam masalah, serta lebih sering menyelesaikan masalah dengan membiarkan anak melakukan kesalahan dalam menyelesaikan masalah secara langsung. Dengan demikian subjek RR tidak memenuhi tahap kemampuan pemecahan masalah pada soal 1.

\section{Soal 2}

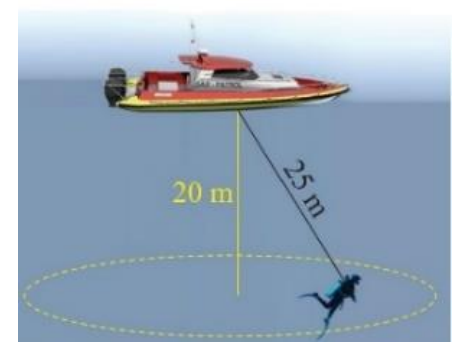

Gambar 5. Gambar Soal 2

Penyelam tim SAR mengaitkan dirinya dengan tali dengan panjang $25 \mathrm{~m}$ dan mencari puing-puing pesawat di dasar laut. Laut yang terendam sedalam $20 \mathrm{~m}$, serta dasar lautnya datar. Berapa luas area yang dapat dicakup oleh seorang penyelam?

Berdasarkan hasil jawaban siswa BD, tampak bisa memahami masalah dengan menulis unsur diketahui, ditanyakan serta membuat gambar secara lengkap. Subjek BD juga dapat menyelesaikan permasalahan yang diberikan dengan lengkap dan memberi kesimpulan, namun tak memeriksa lagi jawabannya. Selaras penelitian Rahmmatiya \& Miatun (2020), Subjek tidak akan mengecek kembali jawaban yang sudah dibuatnya, namun akan menarik kesimpulan dari jawaban yang telah 
Analisis Kemampuan Pemecahan Masalah Matematis Siswa SMP pada Materi Teorema Pythagoras, Alfi Rahmawati, Attin Warmi, Rina Marlina

diperolehnya. Tujuan dari pengecekan ulang jawaban adalah untuk memastikan bahwa perhitungan dan kesimpulan yang dicapai sudah benar (Zulkarnaen, 2021).

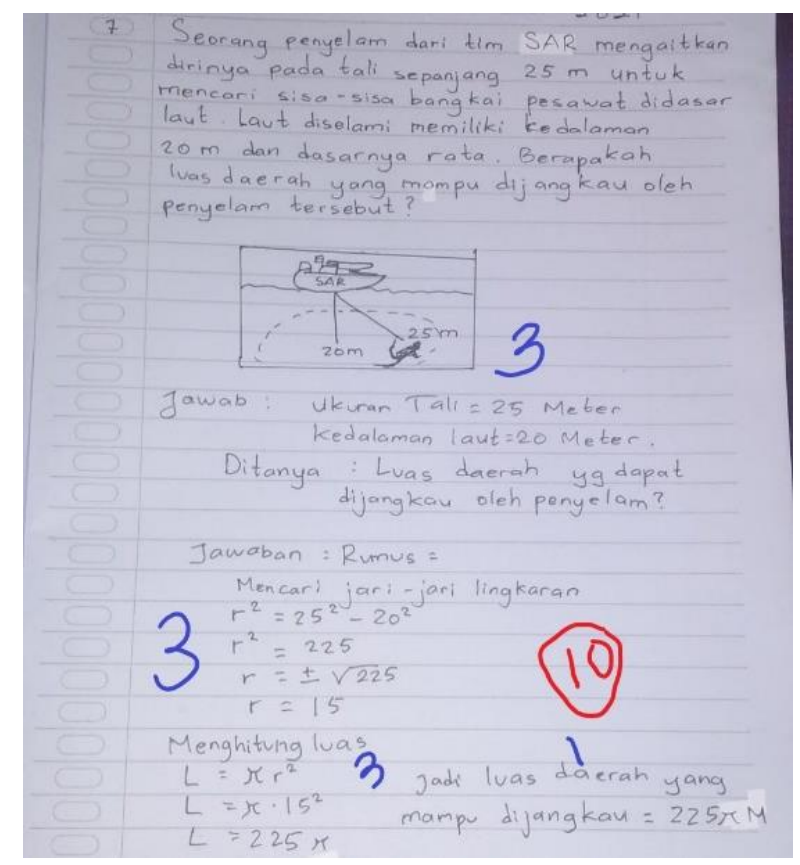

Gambar 6. Hasil Jawaban BD Untuk Soal 2

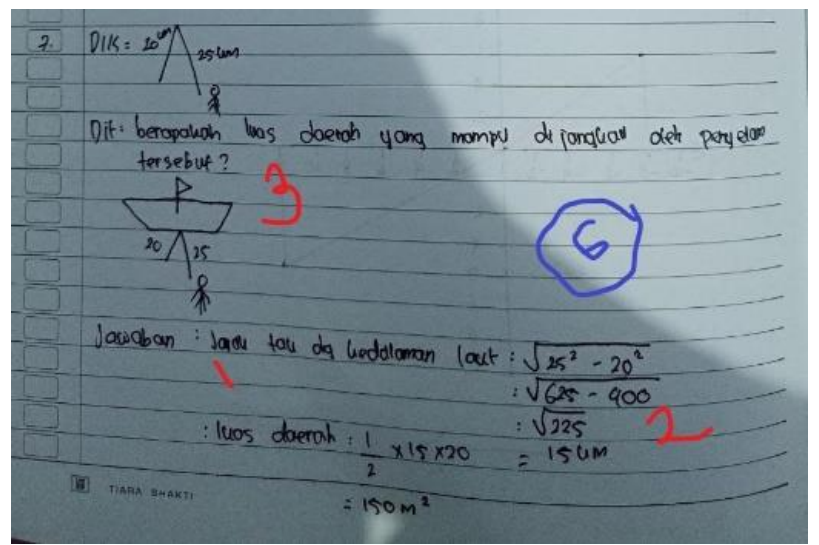

Gambar 7. Hasil Jawaban FFL Untuk Soal 2

Berdasarkan hasil jawaban siswa FFL, tampak bisa memahami masalah dengan menulis unsur yang diketahui, ditanyakan serta membuat gambar secara lengkap. Subjek berhasil mengetahui jarijari atau jarak tali dengan kedalaman laut dengan rumus teorema Pythagoras. Kesalahan yang dilakukan subjek FFL yaitu dalam merencanakan penyelesaiannya tidak menggunakan rumus luas daerah lingkaran atau luas alas kerucut, sehingga tidak memperoleh jawaban yang tepat. Subjek merasa kesulitan mengaitkan informasi yang diberikan lewat pengetahuan milikny. Sejalan dengan penelitian (Zulkarnaen, 2021), siswa kesulitan mengaitkan informasi pada soal dengan pengetahuan yang ada agar bisa membuat rencana penyelesaian tepat. Sehingga pada soal 2 subjek FFL tidak memenuhi tahap kemampuan pemecahan masalah mulai dari tahap menyusun rencana pemecahan masalah. 


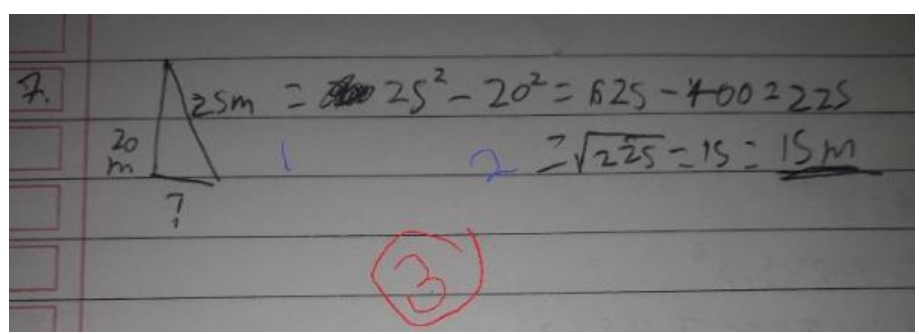

Gambar 8. Hasil Jawaban RR Untuk Soal 2

Dari hasil jawaban siswa RR untuk soal 2, tampak RR memberikan gambar dari informasi yang diberikan pada soal namun tidak lengkap, yaitu jarak kedalaman laut yang dijangkau tali saja, seharusnya masih ada gambar lingkaran untuk menggambarkan luas daerah yang mampu dijangkau penyelam. Sehingga ia hanya melaksanakan penyelesaian sampai menemukan jarak kedalaman laut yang dijangkau tali saja. Dengan demikian subjek RR tidak memenuhi tahap kemampuan pemecahan masalah karena ia masih kesulitan memahami permasalahan yang diberikan di soal 2. Selaras penelitian Maharani \& Bernard (2018) Sulitnya siswa berkemampuan rendah memahami masalah dan menentukan strategi pemecahan masalah, ini diakibatkan minimnya pemahaman konsep di materi yang diujikan, dan siswa tak mampu menyelesaikan masalah sesuai prosedur penyelesaian.

\section{KESIMPULAN}

Dari hasil analisis serta pembahasan kemampuan pemecahan masalah matematika siswa di materi Pythagoras tahap Polya, disimpulkan siswa dengan kemampuan tinggi dapat menyelesaikan masalah yang ada, namun mereka kurang teliti menyelesaikan soal. Baca pertanyaannya agar jawabannya tidak cocok. Siswa pada kategori kemampuan sedang tak bisa menyelesaikan masalah karena hanya bisa memahami masalah yang diberikan. Siswa pada kategori rendah tak bisa menyelesaikan masalah sebab masih kesulitan memahami masalah yang diberikan. Karenanya, proses pembelajaran matematika dalam pemecahan masalah perlu ditingkatkan, sehingga kemampuan pemecahan masalah siswa terasah. Mengingat ada banyak kekurangan di penelitian ini, harapannya peneliti lain lebih mendalami masalah kemampuan pemecahan masalah matematis siswa serta mengetahui berbagai faktor yang memberikan pengaruh.

\section{UCAPAN TERIMA KASIH}

Peneliti menyampaikan terima kasih ke keluarga yang telah mendukung peneliti secara moral maupun material dalam menyelesaikan penelitian ini. Selanjutnya dosen pembimbing ibu Attin Warmi, M.Pd. serta ibu Rina Marlina S.Psi, M.Pd. yang membimbing serta mengarahkan peneliti, Terimakasih disampaikan ke kepala sekolah, wakil kepala sekolah kurikulum sekaligus guru matematika, serta wali kelas IX SMPN 16 Bekasi yang sudah mengizinkan mengadakan penelitian dengan siswa-siswi. Lalu ucapan terimakasih ke para sahabat yang mendukung serta memberi semangat sehingga penelitian berjalan dengan lancar. 
Analisis Kemampuan Pemecahan Masalah Matematis Siswa SMP pada Materi Teorema Pythagoras, Alfi Rahmawati,

\section{REFERENSI}

Abdiyani, S. S., Khabibah, S., \& Rahmawati, N. D. (2019). Profil Kemampuan Pemecahan Masalah Matematika Siswa SMP Negeri 1 Jogoroto Berdasarkan Langkah-langkah Polya Ditinjau dari Adversity Quotient. Al-Khwarizmi: Jurnal Pendidikan Matematika Dan Ilmu Pengetahuan Alam, 7(2), 123-134. https://doi.org/10.24256/jpmipa.v7i2.774

Af-idah, N. Z., \& Suhendar, U. (2020). Analisis Kemampuan Pemecahan Masalah Siswa Berdasarkan Teori Apos Saat Diterapkan Program Belajar Dari Rumah. Jurnal Edupedia, 4(2), 103-112.

Akbar, P., Hamid, A., Bernard, M., \& Sugandi, A. I. (2017). Analisis Kemampuan Pemecahan Masalah Dan Disposisi Matematik Siswa Kelas Xi Sma Putra Juang Dalam Materi Peluang. Jurnal Cendekia: Jurnal Pendidikan Matematika, 2(1), 144-153. https://doi.org/10.31004/cendekia.v2i1.62

Anggraeni, R., \& Kadarisma, G. (2020). Analisis Kemampuan Pemecahan Masalah Matematik Siswa SMP Kelas VII Pada Materi Himpunan. Jurnal Cendekia: Jurnal Pendidikan Matematika, 04(01), 1072-1082.

Ariani, S., Hartono, Y., \& Hiltrimartin, C. (2017). Kemampuan Pemecahan Masalah Matematika Siswa pada Pembelajaran Matematika Menggunakan Strategi Abduktif-Deduktif di SMA Negeri 1 Indralaya Utara. Jurnal Elemen, 3(1), 25. https://doi.org/10.29408/jel.v3i1.304

Arikunto, S. (2018). Dasar-dasar Evaluasi Pendidikan. Bumi Aksara.

Chabibah, L. N., Siswanah, E., \& Tsani, D. F. (2019). PYTHAGORAS: Jurnal Pendidikan Matematika , 14 ( 2 ), 2019 , 199-210 Analisis kemampuan pemecahan masalah siswa dalam menyelesaikan soal cerita barisan ditinjau dari adversity quotient. 14(2), 199-210.

Ekananda, A., Pujiastuti, H., \& S, C. A. H. F. (2020). Analisis Kemampuan Pemecahan Masalah Matematis Ditinjau dari Kemandirian Belajar Siswa. WILANGAN: Jurnal Inovasi Dan Riset Pendidikan Matematika, 1(4), 367-382. http://www.jurnal.untirta.ac.id/index.php/wilangan Intaros, P., Inprasitha, M., \& Srisawadi, N. (2014). Students' Problem Solving Strategies in Problem Solving-mathematics Classroom. Procedia - Social and Behavioral Sciences, 116, 4119-4123. https://doi.org/10.1016/j.sbspro.2014.01.901

Maharani, S., \& Bernard, M. (2018). Analisis Hubungan Resiliensi Matematik Terhadap Kemampuan Pemecahan Masalah Siswa Pada Materi Lingkaran. JPMI (Jurnal Pembelajaran Matematika Inovatif), 1(5), 819. https://doi.org/10.22460/jpmi.v1i5.p819-826

NCTM. (2000). Excecutive Summary Principles and Standards for School Mathematics.

Polya, G. (1988). How To Solve It: A New Aspect of Mathematical Method (Second). Princeton University Press.

Rahmmatiya, R., \& Miatun, A. (2020). Analisis Kemampuan Pemecahan Masalah Matematis Siswa Smp Ditinjau Dari Disposisi Matematis. Teorema: Teori Dan Riset Matematikaendidikan, 5(2), 187-202. https://doi.org/10.31851/wahanadidaktika.v18i2.4387

Sari, N. I. (2020). Analisis Kemampuan Pemecahan Masalah Matematis Peserta Didik Ditinjau Dari 
Kemandirian Belajar Matematika Peserta Didik SMP Negeri 1 Bagan Sinembah Pada Materi Sistem Persamaan Linear Dua Variabel. In Journal of Physics A: Mathematical and Theoretical (Vol. 44, Issue 8). https://doi.org/10.1088/1751-8113/44/8/085201

Towe, M. M. (2019). Analisis Kemampuan Pemecahan Masalah Matematis Siswa dengan Pendekatan PMR Pada Materi Teorema Pythagoras Kelas VIII SMP ST. Aloysius Turi Tahun Ajaran 2018/2019.

Zulkarnaen, R. (2021). Analisis kemampuan pemecahan masalah matematis siswa pada materi segiempat dan segitiga A . Pendahuluan Matematika merupakan salah satu mata pelajaran yang harus dipelajari siswa. Dalam matematika, ada berbagai kemampuan yang harus dikuasai siswa, sala. 12(1), 10-20. 